\title{
STUDI FENOMENOLOGI PENGALAMAN PERAWAT DALAM MEMBERIKAN ASUHAN KEPERAWATAN PALIATIF PADA PASIEN DENGAN PENYAKIT TERMINAL DI RUANG ICU RUMAH SAKIT ADVENT BANDUNG
}

\author{
PHENOMENOLOGICAL STUDY OF NURSES' EXPERIENCE \\ IN PROVIDING PALLIATIVE CARE ON PATIENTS \\ WITH TERMINAL CASE IN INTENSIVE CARE UNIT
}

\author{
Cherley Fanesa Maria Leuna ${ }^{1}$, Jenny Rantung ${ }^{2}$ \\ Fakultas IImu Keperawatan, Universitas Advent Indonesia \\ cherleyleuna@gmail.com
}

\begin{abstract}
ABSTRAK
Pendahuluan: Kebutuhan pasien akan perawatan paliatif di Indonesia semakin meningkat sedangkan pelayanan perawatan yang diberikan oleh perawat masih terbatas dan belum dapat diberikan secara menyeluruh. Tujuan: Tujuan penelitian ini untuk mengeksplorasi pengalaman perawat dalam memberikan asuhan keperawatan paliatif pada pasien terminal. Metode: Penelitian ini menggunakan metode kualitatif dengan pendekatan fenomenologi melalui teknik wawancara mendalam yang melibatkan 6 orang perawat yang bekerja di Ruang Perawatan Kritis ICU Rumah Sakit Advent Bandung, yang dipilih dengan menggunakan metode purposive sampling. Analisa data hasil wawancara mendalam dan semi struktur menggunakan tahap analisis menurut Collaizi. Hasil: Hasil penelitian mendapatkan 5 tema yaitu: Koping Perawat, Adaptasi Perawat, Hambatan dalam proses perawatan, Perilaku caring Perawat dan development of self-efficacy. Diskusi: Saran bagi perawat agar dapat mengikuti seminar - seminar, workshop ataupun pelatihan paliatif guna meningkatkan pengetahuan dan ketrampilan dalam perawatan paliatif. Saran bagi bidang penelitian selanjutnya adalah melakukan penelitian tentang pengalaman keluarga merawat pasien paliatif, atau tingkat pengetahuan perawat dalam menerapkan perawatan paliatif.
\end{abstract}

Kata Kunci: Pasien terminal, Pengalaman perawat, Perawatan paliatif.

\section{ABSTRACT}

Introduction: Client needs in palliative nursing care in Indonesia is increased, while the nursing care that given by a nurse still limited and cannot be given thoroughly. Purpose: The purpose of this study was to explore the experience of nurses in providing palliative care nursing in terminal patients. Method: This research uses qualitative method with phenomenology approach through indepth interview technique that involved 6 nurses working in the Critical Care Room in the Adventist Hospital of Bandung. The selected by using purposive sampling method. Analysis of data result of in-depth interview and semi structure using analysis phase according Collaizi. Results: The results of the research get 5 themes, namely: nurse helmets, nurse adaptation, barriers in the process of care, caring behavior Nurse and development of self-efficacy. Discussion: Advice for nurses to equip themselves by attending seminars, workshops or palliative training to improve knowledge and skills in palliative care. Suggestions for the field of research may carry out other studies such as family experience of caring for palliative patients, patient coping behavior in the treatment process, factors that inhibit terminal patient care processes, the relationship of nurse knowledge level in applying palliative care, caring behavior relationship to quality of life of terminal patients. Suggestions for subsequent 
research are to conduct research on family experience of caring for terminal patients or the nurse knowledge level in applying palliative care.

Keywords: Patient terminal, Experience nurse, Palliative care.

\section{PENDAHULUAN}

Dunia teknologi semakin maju dan modern. Banyak penelitian telah dilakukan, terutama di bidang kesehatan sendiri. Sehingga menghasilkan intervensi terbaru untuk pemecahan masalah yang terjadi. Banyak penyakit menular dapat dicegah, penyakit lainnya dapat diobati, sebagian dilakukan pembedahan dan berbagai cara sesuai dengan kemajuan Ilmu Pengetahuan dan Teknologi yang ada. Tetapi belum ada pengobatan yang dapat memberi kesembuhan pada pasien dengan penyakit terminal.

Pasien dengan penyakit terminal, tidak dapat disembuhkan dengan perawatan secara kuratif. Terapi kuratif dapat membantu mengurangi tanda dan gejala yang dirasakan. Kebutuhan pasien terminal adalah perawatan yang dapat membantu mengurangi penderitaan dari proses penyakit secara fisik, sosial dan psikologi.

Penyakit yang membutuhkan perawatan paliatif yaitu: penyakit kanker, penyakit degeneratif, penyakit paru obstruktif kronis, cystic fibrosis, stroke, Parkinson, gagal jantung/heart failure, penyakit genetika dan penyakit infeksi seperti HIV/AIDS yang memerlukan perawatan paliatif, disamping kegiatan promotif, preventif, kuratif, dan rehabilitatif. (Kepmenkes RI Nomor: 812, 2007).
Sejak tahun 2005, WHO mencanangkan terapi holistik yang disebut sebagai perawatan paliatif (palliative care). Perawatan paliatif adalah sistem perawatan terpadu untuk meningkatan kualitas hidup, dengan meringankan nyeri, dan penderitaan lain, memberikan dukungan spiritual dan psikososial mulai sejak diagnosa ditegakan sampai akhir hayat dan dukungan terhadap keluarga yang merasa kehilangan atau berduka. Kematian merupakan konsekuensi paling buruk yang dialami seorang pasien dengan penyakit terminal. Kondisi kritis menuju kematian menjadi tahapan kehidupan yang paling menakutkan bagi setiap orang (Benini, 2008).

Di Indonesia, perawatan paliatif telah diperkenalkan ke dalam sistem pelayanan kesehatan di Indonesia sejak tahun 1989, melalui Peraturan Menteri Kesehatan

No. 604/MENKES/SK/IX/1989 tentang program pengendalian Kanker

Nasional. Dengan peraturan ini, pemerintah menciptakan empat kelompok kerja, salah satunya difokuskan pada pengembangan perawatan paliatif dan manajemen nyeri untuk pasien kanker. Perawatan paliatif telah dimulai sejak tahun 1992 dan telah menjadi agenda pemerintah Indonesia pada tahun 2007 dengan diterbitkannya Keputusan Menteri Kesehatan Republik Indonesia No.812/Menkes/SK/VII/2007 tentang Kebijakan Perawatan Paliatif. 
Di Indonesia Rumah sakit yang mampu memberikan pelayanan perawatan paliatif masih terbatas di lima ibu kota propinsi yaitu Jakarta, Yogyakarta, Surabaya, Denpasar dan Makassar. Ditinjau dari besarnya kebutuhan dari pasien, jumlah dokter yang mampu memberikan pelayanan perawatan paliatif juga masih terbatas. Keadaan sarana pelayanan perawatan paliatif di Indonesia masih belum merata sedangkan pasien memiliki hak untuk mendapatkan pelayanan yang bermutu, komprehensif dan holistik, maka diperlukan kebijakan perawatan paliatif di Indonesia yang memberikan arah bagi sarana pelayanan kesehatan untuk menyelenggarakan pelayanan perawatan paliatif. (Kepmenkes RI Nomor: 812, 2007).

Penelitian Davies et al (2008) menyatakan bahwa hambatan dalam memberikan paliatif yaitu akses terbatas penyedia perawatan paliatif, ketidakpastian dalam prognosis dan hasil pengobatan dan kurangnya komunikasi serta hambatan dari pemberi perawatan. Banyak penelitian telah mencatat bahwa kurangnya pendidikan dan pelatihan keterampilan adalah penghalang untuk perawatan paliatif.

Untuk pengembangan dan peningkatan mutu perawatan paliatif diperlukan pemenuhan sarana, prasarana dan peralatan kesehatan dan non kesehatan, pendidikan dan pelatihan yang berkelanjutan/Continuing Professional Development untuk perawatan paliatif (SDM) untuk jumlah, jenis dan kualitas pelayanan, menjalankan program keselamatan pasien/patient safety. (Kepmenkes RI Nomor: 812, 2007).
Pihak yang terlibat dalam pelayanan perawatan paliatif salah satu diantaranya adalah perawat. Pelayanan yang diberikan berupa asuhan keperawatan secara langsung kepada pasien (individu dan keluarga) sesuai dengan kriteria dan kompetensi modul pelatihan yang terstandar. Dengan harapan bahwa perawat dapat mengetahui lebih jauh mengenai kesehatan pasien dan keluarga. Serta mampu mengidentifikasi, mengkaji, memberikan dan mengelola sesuai asuhan keperawatan paliatif. (Asmadi, 2008).

Hasil studi pendahuluan yang dilakukan pada bulan Maret 2014 didapatkan data bahwa jumlah anak yang menerima perawatan paliatif di Yayasan Rumah Rachel pada tahun 2013 adalah sebanyak 350 anak menderita kanker dan HIV. Anak sebanyak $70 \%$ dari penderita paliatif terminal tersebut meninggal dengan rasa nyaman.

\section{METODE}

Desain yang digunakan dalam penelitian ini adalah metode penelitian studi fenomenologi. Metode kualitatif digunakan untuk menggali karakteristik pengalaman perawat dalam memberikan asuhan keperawatan paliatif pada pasien dengan penyakit terminal. Pendekatan yang digunakan seperti yang di atas yaitu, pendekatan induktif fenomenologi. Fokus penelitian adalah pada karakteristik pengalaman perawat dalam memberikan asuhan keperawatan paliatif pada pasien dengan penyakit terminal. Tujuan menggunakan pendekatan induktif adalah menggali fenomena karakteristik pengalaman 
perawat dalam memberikan asuhan keperawatan paliatif. Sampel yang digunakan pada penelitian adalah perawat yang bekerja di Ruang ICU Rumah Sakit Advent Bandung, dan memiliki pengalaman bekerja minimal tiga tahun di ICU dalam merawat pasien terminal.

Kriteria yang digunakan untuk memilih sampel dalam penelitian ini adalah sampel merupakan perawat yang bekerja di Ruang ICU Rumah Sakit Advent Bandung. Dengan kriteria pendidikan minimal D3 Keperawatan, memiliki pengalaman klinik minimal tiga tahun dalam merawat pasien terminal. Berdomisili di Bandung dan berkewarganegaraan Indonesia serta bersedia dalam penelitian. Sampel berjenis kelamin perempuan dan lakilaki.

\section{HASIL DAN PEMBAHASAN}

\section{Gambaran Tempat Penelitian}

Saat ini perawat di Ruang Perawatan ICU, Rumah Sakit Advent Bandung berjumlah 21 orang, terdiri dari 19 perawat yang telah bersetifikat dan mendapatkan pelatihan keperawatan kritis selama 3 bulan dianataranya pelatihan ACLS dan BTCLS dimana pelatihan ini memberikan pengetahuan dan

meningkatkan ketrampilan perawat yang bekerja diruang perawatan kritis. Perawat S1 berjumlah 19 orang dan perawat D3 berjumlah 2 orang. Selain itu staff di Ruang perawatan ICU Rumah Sakit Advent Bandung sebagai tenaga penunjang atau Nurse Aid 3 orang, administrasi 1 orang dan teknisi 1 orang,1dokter kepala instalasi dan hanya 1 dokter saja yang bertugas sebagai dokter penanggungjawab harian dan 1 perawat sebagai supervisor atau penanggung jawab mutu.

\section{Gambaran Key Informant Penelitian}

Partisipan dalam penelitian ini adalah perawat yang bekerja di Ruang Perawatan Kritis ICU, Rumah Sakit Advent Bandung. Karakteristik dari masing-masing partisipan dalam penelitian ini akan diuraikan sebagai berikut:

Tabel 1. Karakteristik Partisipan

\begin{tabular}{|c|c|c|c|c|}
\hline Inisial & Umur & $\begin{array}{l}\text { Pendidikan } \\
\text { Terakhir }\end{array}$ & $\begin{array}{l}\text { Tempat } \\
\text { Bekerja }\end{array}$ & $\begin{array}{c}\text { Pengalaman } \\
\text { Bekerja }\end{array}$ \\
\hline $\begin{array}{l}\text { lbu A } \\
\text { (K1) }\end{array}$ & $\begin{array}{l}32 \\
\text { Tahun }\end{array}$ & D3 Kep & ICU & 7 tahun \\
\hline $\begin{array}{l}\text { Bapak } \\
\text { R } \\
\text { (K2) }\end{array}$ & $\begin{array}{l}31 \\
\text { Tahun }\end{array}$ & $\begin{array}{l}\text { S-1 Kep } \\
\text { Ners }\end{array}$ & ICU & 7 tahun \\
\hline $\begin{array}{l}\text { Ibu L } \\
\text { (K3) }\end{array}$ & $\begin{array}{l}32 \\
\text { Tahun }\end{array}$ & $\begin{array}{l}\text { S-1 Kep } \\
\text { Ners }\end{array}$ & $\mathrm{HCU}$ & 5 tahun \\
\hline $\begin{array}{l}\text { Ibu E } \\
\text { (K4) }\end{array}$ & $\begin{array}{l}50 \\
\text { Tahun }\end{array}$ & D3 Kep & ICCU & $\begin{array}{l}20 \text { tahun di } \\
\text { ICU }\end{array}$ \\
\hline $\begin{array}{l}\text { Bapak } \\
\text { A (K5) }\end{array}$ & $\begin{array}{l}47 \\
\text { Tahun }\end{array}$ & $\begin{array}{l}\text { S-1Kep } \\
\text { Ners }\end{array}$ & ICU & 24 tahun \\
\hline $\begin{array}{l}\text { Ibu H } \\
(\mathrm{K} 6)\end{array}$ & $\begin{array}{l}39 \\
\text { Tahun }\end{array}$ & $\begin{array}{l}\text { S1 Kep } \\
\text { Ners }\end{array}$ & ICCU & 12 Tahun \\
\hline
\end{tabular}

Responden yang memenuhi kriteria diberikan penjelasan tentang tujuan dan manfaat penelitian, serta risiko yang mungkin dialami selama penelitian. Responden yang menyatakan bersedia untuk ikut sebagai responden penelitian, diminta menandatangani informed consent.

Wawancara yang dilakukan oleh Investigator kepada para Key Informant dilakukan dalam kurun waktu 10-20 menit. Jumlah Key Informant dalam penelitian ini adalah enam orang, yang terdiri dari empat 
wanita dan dua laki-laki yang memiliki pengalaman kerja miminal 3 tahun dalam merawat pasien terminal melalui purposive Sampling.

Pada wawancara tahap pertama diikuti oleh enam partisipan dan pada tahap kedua diikuti oleh lima partisipan. Karena Key Informant kelima mengundurkan diri dalam penelitian. Key Informant disingkat sebagai KI.

Pengambilan data dilaksanakan di Ruang Perawatan Kritis ICU Rumah Sakit Advent Bandung pada pada tanggal 01 Maret 2018 sampai 05 April 2018.

Pada pengambilan data melalui metode wawancara semi struktur, dilakukan dengan rata-rata waktu selama 5-10 menit. Setelah peneliti mendapatkan semua data dari ke enam Key Informant, peneliti melakukan FGD.

Focus Group Discussion (FGD), atau yang disebut dengan Diskusi Kelompok Terarah dilakukan pada tanggal 09 April 2018, jam 09.30 WIB di ruangan ICCU, lantai 2, Rumah Sakit Advent Bandung. Jumlah Key Informant yang hadir dalam FGD adalah sebanyak 4 orang, dan 1 orang Key Informant dilakukan by phone (wawancara melalui telepon seluler), karena tidak dapat hadir saat dilakukan FGD. Tujuan dari dilakukanya FGD adalah untuk memfalidasi data yang telah diperoleh dari Key Informant, serta mengaklarifikasi setiap jawaban dari Key Informant dan menuliskan data baru yang didapatkan saat melakukan FGD pada hasil transkrip yang lengkap.

\section{Hasil Penelitian dan Pembahasan}

Hasil penelitian menemukan lima tema utama yang menggambarkan pengalaman perawat dalam memberikan asuhan keperawatan paliatif pada pasien terminal berdasarkan Teori from Novice To Expert Benner, Teori Adaptasi Roy, Teori Science of Caring Watson dan Teori Self-efficacy Bandura.

Beberapa teori keperawatan yang digunakan pada pembahasan hasil penelitian, sesuai dengan pengalaman yang dialami oleh Key Informant. Seperti Teori from Novice to Expert dari Benner, dimana teori ini menggambarkan pengalaman Key Informant, sebagai perawat Novice/pemula pada pengalaman pertama merawat pasien terminal dan menjadi proficient/perawat yang cakap dalam pekerjaanya.

Tema yang muncul sebagai hasil dari penelitian adalah: Koping Perawat, Adaptasi Perawat, Hambatan dalam proses perawatan, Perilaku caring Perawat dan development of selfefficacy. Bagian berikut diuraikan secara jelas masing-masing tema.

\section{Koping Perawat}

Tema pertama yang muncul ini adalah berdasarkan pengalaman terbanyak yang dialami oleh Key Informant, dapat terlihat pada tabel berikut: 
Tabel 2. Tema ke-1

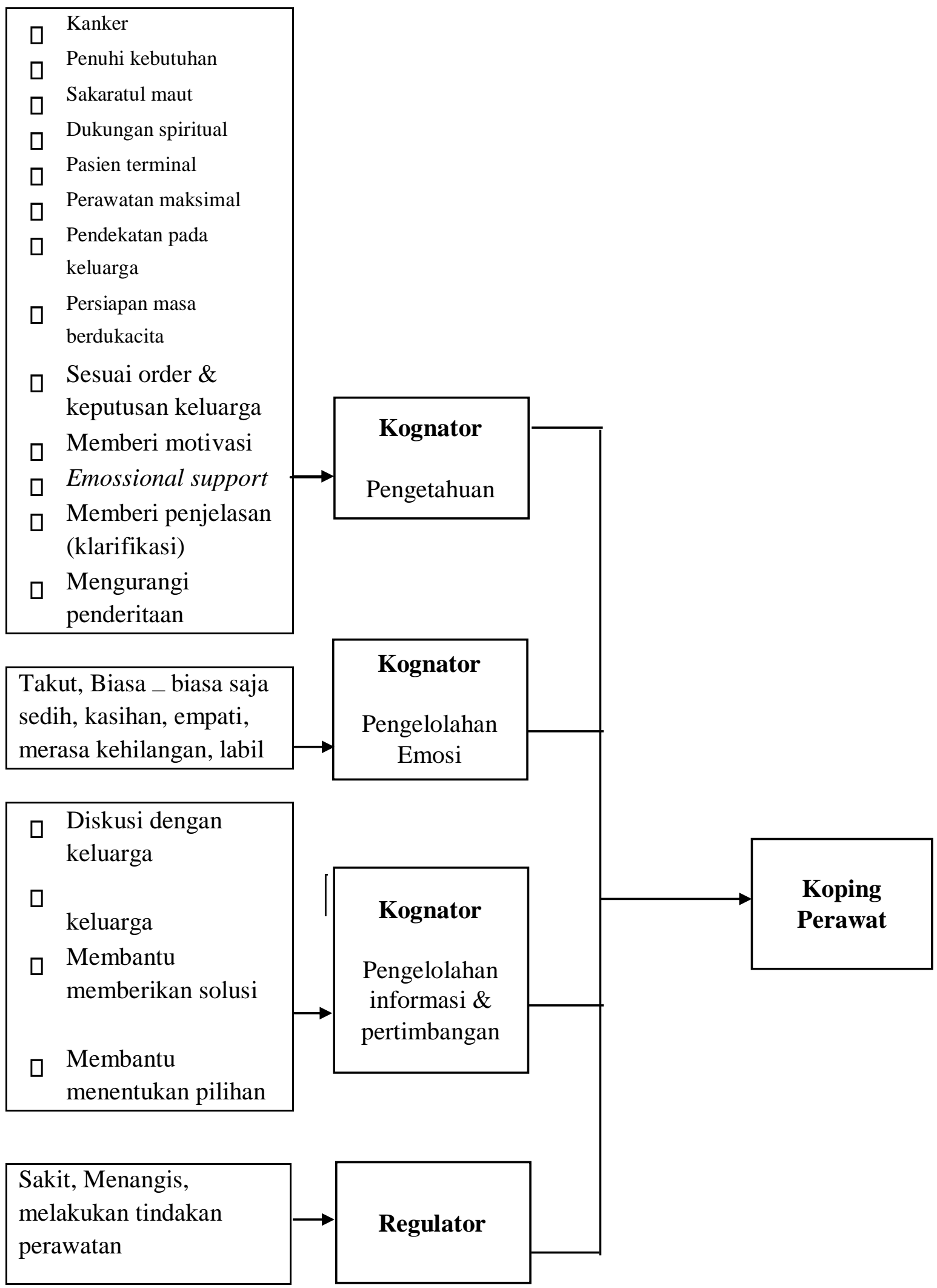


Jawaban hasil wawancara Key Informant sehubungan dengan pengetahuan dan pemahaman tentang perawatan paliatif pada pasien terminal adalah sesuai dengan pembahasan pada bab dua, konsep dasar keperawatan adalah paliatif.

Data yang didapat berdasarkan hasil wawancara, Key Informant menjawab bahwa perawatan paliatif diberikan kepada pasien kanker, tetap memenuhi kebutuhan sampai sakaratul maut, memberikan dukungan spiritual, memberikan perawatan yang maksimal sesuai dengan order dokter dan permintaan dari keluarga, memberikan motivasi, emossional suport, memberikan penjelasan tentang kondisi pasien atau melakukan klarifikasi kepada keluarga, mengurangi penderitaan pasien, melakukan pendekatan pada keluarga dan mempersiapkan keluarga untuk masa berdukacita. Hal ini sesuai dengan Kepmenkes (2013), Perawatan paliatif diperlukan karena: Setiap orang berhak dirawat dan mati secara bermartabat, menghilangkan nyeri: fisik, emosional, spiritual dan sosial adalah hak asasi manusia, perawatan paliatif adalah kebutuhan mendesak seluruh dunia untuk orang yang hidup dengan penyakit terminal lanjutan.

Penyakit yang membutuhkan perawatan paliatif yaitu: penyakit kanker, penyakit degeneratif, penyakit paru obstruktif kronis, cystic fibrosis, stroke, Parkinson, gagal jantung/heart failure, penyakit genetika dan penyakit infeksi seperti HIV/AIDS yang memerlukan perawatan paliatif, disamping kegiatan promotif, preventif, kuratif, dan rehabilitatif. (Kepmenkes RI Nomor: 812, 2007).

Dari hasil wawancara didapati satu dari partisipan mengungkapkan perawatan paliatif cenderung untuk pasien kanker, tiga partisipan lain mengungkapkan tetap memberikan perawatan yang maksimal sesuai order dokter dan keputusan keluarga sampai sakaratul maut, satu partisipan mengungkapkan pentingnya dukungan spiritual dan satu partisipan lain mengungkapkan pasien paliatif perlu diberikan motivasi, semangat, emossional support, dan memberikan penjelasan tentang kondisi selama proses perawatan. Berikut pernyataan partisipan, yaitu:

“...paliatifkan sebenarnya dia cenderungnya untuk ya pasien yang kanker...

“...berikan kebutuhannya
walaupun disaat - saat yang
sakaratul maut ya kita penuhi
kebutuhan dia..."

...pasien yang sudah jelek menuju sakaratul maut perlu di itu perlu dukungan spiritualnya juga..."

“...paliatif itu ya pasien - pasien terminal ya? Perawatan pada pasien - pasien terminal..." 
“...melakukan perawatan yang semaksimal walaupun dia terminal..."

“...tetap memberikan e perawatan terapi sampai titik penghabisan, kecuali keluarga menolak..."

“...pendekatan pada keluarga, untuk mempersiapkan e apa mental mereka untuk menghadapi kematian..."

“...memberikan perawatan sesuai order, sesuai keputusan keluarga juga..."

“...ya kita dukung kita kasih motivasi, pasien semangat, kasih emosional support, tetap kita kasih penjelasan...

“...nggak ${ }_{\text {penderitaanya... }}$ memperpanjang

Hasil wawancara berikutnya pada pengalaman yang dialami Key Informant dalam pengelolahan emosi saat memberikan perawatan, perawat mengalami stres kerja pada awalnya. Dimana Key Informant merasakan takut saat pertama kali merawat pasien terminal, karena lingkungan kerja yang baru dan memerlukan adaptasi tentang penggunaan alat dan perawatan pada pasien yang tidak sadar.

Menurut Ashby (2009) bahwa stress dapat juga terjadi karena orang tersebut tidak merniliki sumber daya dan ketrampilan yang bisa membantunya memecahkan masalah yang dihadapi. Pendapat ini juga dikemukakan berdasarkan penelitian di Jerman (2008) tentang stess kerja, bahwa perawat perlu mengenal sumber stress dulu untuk terbebas dari permasalahannya.

Hal ini juga sesuai dengan penelitian dari De weerdt (2008) mengatakan ada pengaruh yang kuat dari tingkat lamanya pengalaman seseorang terhadap kemampuan untuk mengatur emosi. Pengaruh lamanya pengalaman dapat bersifat langsung maupun tidak langsung terhadap pengaturan emosi. Perawat yang tidak memiliki pengalaman pada lingkungan kerja yang baru memerlukan adaptasi terhadap pengaturan emosi dan stress saat melakukan pekerjaan.

Dari hasil wawancara yang dilakukan pada keenam Key Informant didapati dua dari partisipan mengungkapkan perasaan takut ketika pertama kali merawat pasien tidak sadar, karena lingkungan kerja yang baru dan belum mengetahui cara mengoperasikan peralatan di ICU. Dua partisipan lain mengungkapkan perasaanya biasa - biasa saja tidak ada rasa takut, saat pertama kali merawat pasien yang tidak sadar atau pasien kritis Tetapi dua dari partisipan ini merasa kasihan, empati, dan sedih melihat kondisi yang dirasakan pasien dan keluarga dan satu partisipan lain mengungkapkan memiliki perasaan yang labil ketika berkomunikasi dengan keluarga yang labil atau panik saat dihadapkan dengan pengambilan 
keputusan. Berikut pernyataan partisipan, yaitu:

“...sebenarnya sih emang awalnya e masuk ke ICU itu ya takut sih untuk merawat pasien yang nggak sadar..."

“...perasaanya mah biasa - biasa aja, nggak ada rasa takut..."

“...yang pasti pertama itu ada rasa takut, takut salah..."

“...pertama pengalamanya ya sedih..."

“...selanjutnya ya masih sama masih merasakan kasihan...

“...nggak ada rasa takut, biasa aja, paling kasihan, empati kita ya...”

“...mengalami apa yang dia rasakan..."

“...semua pasien di ICU kasihan gua..."

"...turut merasakan bagaimana rasa sakit yang dia rasakan setiap hari..."

“...merasa kehilangan banget...”

“...yang pastinya perasaan sedih itu ada ya, kasihan..."

“...pernah dulu dirawat di ICU, cuman ya saat dia meninggal ya kita merasa itulah yang terbaik buat dia, maksudnya sedih juga, ya itu tadi empati..." “...karena mereka panik trus keputusannya labil nah itu kadang membuat kita juga jadi labil."

Selain itu didapatkan juga pengalaman partisipan dalam Pengelolahan informasi \& pertimbangan, yaitu: berdiskusi dengan keluarga tentang kondisi kesehatan pasien, memberi jawab pada keluarga yang sering bertanya, membantu memberikan solusi dan membantu keluarga menentukan dalam proses perawatan.

Hal ini tentu sesuai dengan hasil penelitian yang dilakukan oleh Latour, dkk (2009), menyatakan bahwa sebagian besar perawat intensive care Eropa terlibat dalam diskusi dengan keluarga tentang akhir kehidupan dan proses pengambilan keputusan oleh keluarga.

Salah satu peran perawat menurut Potter dan Perry (2010) adalah peran pemberi perawatan dimana perawat memfokuskan asuhan pada kebutuhan kesehatan pasien secara holistik, meliputi upaya mengembalikan kesehatan emosi, spiritual dan sosial. Sejalan dengan tujuan dari perawatan paliatif Pada tahap ini pengalaman Key Informant dikategorikan sebagai proses adaptasi kognator, sesuai dengan teori yang dikemukakan oleh Roy, terdapat dua mekanisme kontrol. Yang terbagi atas regulator dan kognator yang merupakan subsistem.

Kognator merupakan gambaran respon yang berkaitan dengan 
perubahan kognitif dan emosi, termasuk didalamnnya persepsi, proses informasi, pembelajaran, membuat alasan dan emosional (Wills, 2011). Menurut Roy, Stimulus untuk subsistem kognator dapat secara eksternal maupun internal. Perilaku output dari subsistem regulator dapat menjadi stimulus umpan balik untuk subsistem kognator.

Kognator kontrol proses berhubungan dengan fungsi otak dalam memproses informasi, penilaian dan emosi. Persepsi atau proses informasi berhubungan dengan proses internal dalam memilih atensi, mencatat dan mengingat. Belajar berkorelasi dengan proses imitasi, reinforcement (penguatan) dan insight (pengertian yang mendalam).

Penyelesaian masalah dan pengambilan keputusan adalah proses internal yang berhubungan dengan penilaian atau analisa. Emosi adalah proses pertahanan untuk mencari keringanan, mempergunakan penilaian dan kasih sayang.

Dari hasil wawancara didapati dua dari partisipan mengungkapkan ada keluarga yang menolak memberikan tindakan perawatan maka hal tersebut akan didiskusikan bersama keluarga untuk pengambilan keputusan terkait dengan menandatangi informed consent atau form penolakan, satu partisipan lain mengungkapkan ada juga pasien dan keluarga yang mengalami denial atau menolak, tidak menerima maka partisipan menganjurkan untuk lebih banyak berdoa biar keluarga dapat lebih iklas. Berikut pernyataan partisipan, yaitu:

"...jadi memang ada keluarga yang menolak ya tinggal suruh aja mereka tanda tangan tapi harus diingetin bahwa udah kata sepakat dari keluarga..."

“...keluarga yang menolak segala sesuatu terapi yang diberikan dan itu harus ditanda tangan di informed consent, e penolakan rawat inap dengan terapi dan serta yang lain - lainnya. Ada form penolakan disitu “

“...ada keluarga yang yang menerima ada yang tidak menerima, awal-awalnya mereka tidak menerima, misalnya banyak bertanya, biasanya kita anjurkan mereka banyak berdoa biar lebih iklas kan itu sih biasanya..."

Data berikut dari hasil wawancara didapatkan bahwa Key Informant mengalami respon regulator. Respon regulator adalah respon terhadap fisiologi tubuh, dimana hal ini dialami oleh perawat saat memberikan perawatan kepada pasien, perawat merasakan proses empati yang membuat perawat tidak hanya menangis tetapi juga bahkan bisa sampai jatuh sakit karena memikirkan pasien yang dirawat.

Menurut Roy, subsistem regulator mempunyai komponenkomponen: 
input-proses dan output. Input sebagai stimulus dapat berupa internal atau eksternal. Transmiter subsistem regulator adalah kimia, neural atau endokrin. Refleks otonom adalah respon neural brain sistem dan spinal cord yang diteruskan sebagai perilaku output dari subsistem regulator. Banyak proses fisiologis yang dapat dinilai sebagai perilaku subsistem regulator.

Hasil penelitian Thomas et al (2009) yang mengatakan bahwa dalam proses perawatan, perawat yang sering menunjukkan sikap caring dengan cara berbicara dengan ramah dan santun, mempunyai perhatian, penuh minat dalam menolong klien, dan membina hubungan yang saling menguntungkan dengan penampilan yang relijius dalam setiap melakukan tindakannya. Dapat mengalami proses empati yang dalam terhadap pasien. Seperti menangis, merasa kehilangan yang dalam terhadap pasien yang dirawat.

Dari hasil wawancara didapati satu dari partisipan mengungkapkan merasakan empati yang dalam sampai terbawa emosi yang bisa membuatnya menangis dan bahkan sampai sakit, dan satu partisipan lain mengungkapkan merasakasihan dengan kondisi pasien, satu partisipan lain mengungkapkan tetap menjalankan proses perawatan sesuai permintaan keluarga walaupun sudah tidak ada harapan untuk sembuh. Berikut pernyataan partisipan, yaitu:

“.... ikut merasakan apa yang $e$ pasien itu rasakan sih, jadi kadang bisa e kebawa emosi, bisa sakit, bisa nangis, bisa sampe nangis gitu..."

“...semua pasien di ICU kasihan gua, nafas - nafas aja nggak bisa, masih perlu dibantuin gitu, tensi aja itu dibantu bantu..."

“...ada juga emang keluarga yang sampe tidak ada harapanpun minta dibuatin maksimal ..."

\section{Proses Adaptasi}

Tema kedua yang muncul adalah berdasarkan pengalaman kedua terbanyak yang dialami oleh Key Informant, dapat terlihat pada tabel berikut: 
Tabel 3 Tema ke-2

\section{Kode}

Kategori

Tema

\begin{tabular}{|cl|}
\hline$\square$ & Pengalaman baru \\
$\square$ & Lingkungan kerja yang \\
& baru \\
$\square$ & Takut \\
$\square$ & Butuh adaptasi \\
$\square$ & Pengetahuan masih \\
& terbatas \\
$\square$ & Butuh ketrampilan \\
& khusus perawatan \\
& terminal \\
\hline
\end{tabular}

( Sudah memiliki pengalaman sebelumnya pada bidang yang sama

๑ Terlibat dengan keluarga dalam proses perawatan

․ Memenuhi sesuai kebutuhan

¿ Mengetahui kondisi berdasarkan proses penyakit

( Memberikan perawatan secara menyeluruh (holistik)

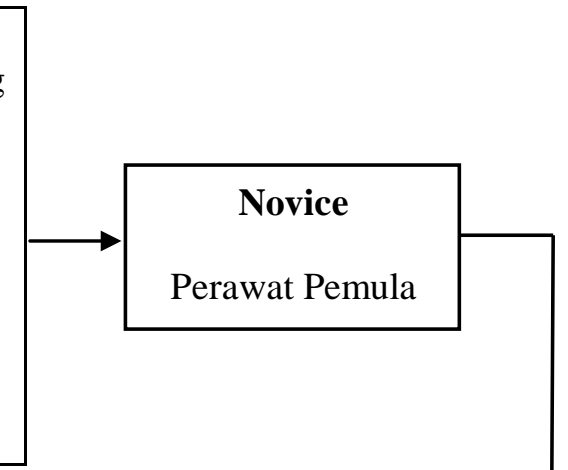

Inisiatif
口 Awal bekerja butuh penyesuaian
口 Mampu beradaptasi
․ Mampu menghadapi kondisi pasien \& keluarga
․ Merasa senang merawat melakukan perawatan

Data yang didapat berdasarkan wawancara, ditemukan pada pengalaman pertama Key Informant setelah mengalami rotasi tempatkan kerja yang baru pertisipan merasa takut dalam merawat pasien yang tidak sadar, merasa takut apabila salah mengoperasikan peralatan, takut salah 
ketika memberikan perawatan pada pasien.

Tetapi ada juga yang merasa biasa biasa saja karena menurut mereka merawat pasien di ICU sama halnya dengan merawat pasien pada Ruang Perawatan biasa dan juga ada yang mengalami perasaan sedih karena keluarga pasien yang mengalami perpisahan dengan orang terdekat mereka.

Berbeda dari pengalaman kerja ditempat sebelumnya, maka pada tahap ini perawat membutuhkan adaptasi dengan lingkungan tempat kerja yang baru, dengan proses perawatan yang kompleks, perlatan yang berbeda - beda dan sebagai perawat ICU tentu dituntut untuk dapat mengoperasikan peralatan tersebut dengan baik dalam memberikan perawat pada pasien.

Berdasarkan teori from Novice to Expert oleh Benner, maka pada pengalaman pertama ini, Key Informant digambarkan sebagai perawat novice. Novice adalah seorang pemula tanpa pengalaman dibidang yang sama.

Menurut Benner, pada tahap ini seseorang tanpa latar belakang pengalaman pada situasinya, maka perintah yang jelas dan atribut yang obyektif harus diberikan untuk memandu penampilannya, disini perawat sulit untuk melihat situasi yang relevan dan irrelevan, pada tahap ini Benner mengklasifikasikan perawat pada level novice, jika ditempatkan pada area atau situasi yang tidak familiar dengannya.

Ferell, dkk. (2010) yang menyatakan bahwa perawat tidak dapat mempraktikkan apa yang mereka tidak ketahui, sehingga dibutuhkan peningkatan pengetahuan perawat melalui kegiatan seminar atau pelatihan.

Adhisty, dkk (2016) menyatakan bahwa tenaga kesehatan khususnya perawat memiliki beberapa hambatan dalam melakukan perawatan paliatif ini antara lain terbatasnya pengetahuan perawat mengenai bagaimana cara pemberian perawatan paliatif yang berkualitas dan bagaimana menyiapkan kepribadian perawat agar pelayanan paliatif dapat dioptimalkan pemberiannya

Penelitian yang dilakukan oleh Ari dan Insook (2013) menyatakan bahwa perawat spesialis 2 (Expert) memiliki persepsi yang lebih baik dalam penanganan dan pemberian perawatan dari pada perawat spesialis 1 (Competent/Proficient), perawat generalis (Novice/Advance Beginner), dan perawat baru (New Nurse).

Menurut Sitinjak (2008), Pelayanan kesehatan yang bermutu ditentukan oleh kualitas sumber daya manusia (SDM). Salah satu upaya meningkatkan mutu pelayanan adalah dengan adanya pengembangan staf melalui pengembangan karir perawat. Pengembangan karir perawat melalui jenjang karir terbukti dapat meningkatkan kepuasan kerja dan peningkatan kinerja perawat.

Hal ini didukung dengan penelitian Mc Ilfatrick, Mawhinney, dan Gilmour (2010) mengatakan pendidikan dan pelatihan sangat penting untuk meningkatkan kualitas paliatif dan perawatan akhir hidup bagi pasien. Pengembangan perawat profesional perawatan paliatif memiliki potensi untuk mengatasi beberapa tantangan yang ada dalam pemberian perawatan 
paliatif dan membantu menjembatani kesenjangan antara spesialis juga generalis pada perawatan paliatif.

Dari hasil wawancara didapati dua dari partisipan mengungkapkan, pada pengalaman pertama bekerja di ICU setelah mengalami rotasi mereka merasa takut dan satu partisipan lain mengungkapkan mengalami perasan yang sedih pertama kali merawat pasien karena merasa kehilangan. Dan kelima partisipan ini setujuh bahwa mereka perlu diberikan seminar - seminar ataupun pelatihan paliatif guna meningkatkan pengetahuan dan ketrampilan dalam melakukan perawatan paliatif. Berikut pernyataan partisipan, yaitu:

"...Sebenarnya sih emang awal awalnya masuk ke ICU itu, ya takut sih untuk merawat pasien yang nggak sadar..."

“...takut sih, tapi mengambil sisi positifnya biar ilmunya juga bisa bertambah, berkembang sama ketrampilannya..."

“...belum pernah ikut seminar tentang paliatif, harusnya pelatihannya juga perlu sih, biar kita digali juga ilmunya up to date..."

“...perlu juga difasilitasi dengan seminar atau pelatihan pada SDM ya itu boleh biar lebih di asa..."

“...Yang pasti pertama itu masuk ada rasa takut, karena yang pertama baru masuk ICU, ya takut, pasti takut salah..."

“.... seharusnya dibuka pelatihan yang memang khusus supaya perawatnya bisa lebih caring...' “...pengalaman pertamanya ya sedih ya, karena pasti keluarga akan merasa kehilangan e keluarganya ya..."

"...boleh dikasih seminar ya soalnya saya belum pernah sepertinya ya supaya lebih menambah wawasan..."

Belajar dari pengalaman sebelumnya dengan lingkungan kerja yang sama, membuat Key Informant menjadi lebih terbiasa dan semakin baik dalam memberikan perawatan pada pasien terminal.

Pada pada tahap ini perawat menunjukkan kemampuan dalam pengelolahan ketrampilannya sesuai dengan pengetahuan yang diperoleh, juga memberikan perawatan dengan lebih menyeluruh atau holistik dan lebih banyak berkomunikasi serta melibatkan keluarga dalam proses perawatan.

Hal ini sesuai dengan data yang diperoleh saat wawancara. Dimana Key Informant memiliki pengalaman beberapa tahun pada lingkungan kerja yang sama, melibatkan keluarga dalam proses perawatan, memenuhi sesuai yang kebutuhan pasien, mengetahui kondisi yang terjadi berdasarkan proses penyakit pasien, memberikan perawatan secara menyeluruh (holistik) dan inisiatif dalam melakukan perawatan.

Pada tahap ini Key Informant digambarkan sebagai perawat Proficient atau perawat cakap didalam pekerjaanya. Ini didukung oleh teori Benner, bahwa perawat dikatakan sebagai Proficient ketika dia menunjukkan kemampuan untuk 
melihat perubahan yang relevan pada situasi, meliputi: pengakuan dan mengimplementasikan respon ketrampilan dari situasi yang dikembangkan, mereka mendemonstrasikan peningkatan percaya diri pada pengetahuan dan ketrampilannya, pada tingkat ini perawat banyak terlibat dengan keluarga.

Hal ini didukung oleh penelitian yang dilakukan oleh Ari dan Insook (2013) menyatakan bahwa perawat spesialis 2 (Expert) memiliki persepsi yang lebih baik dalam penanganan dan pemberian perawatan dari pada perawat spesialis 1 (Competent/Proficient), perawat generalis (Novice/Advance Beginner), dan perawat baru (New Nurse).

Dari hasil wawancara didapati dua dari partisipan mengungkapkan bahwa pasien yang membutuh perawatan dinilai saat pertama kali masuk ICU, dan tiga partisipan lain mengungkapkan memberikan perawatan dengan cara memenuhi kebutuhan secara menyeluruh atau holistik. Baik itu saat memberikan obat, saat memberikan bantuan nafas, memonitoring tensi, berkomunikasi dengan keluarga, menghadirkan pemuka agama, memberi klarifikasi kepada keluarga melalui nomor telepon yang ditinggalkan agar dapat dihubungi dan satu partisipan lain mengungkapkan pada keadaan terminal lanjutan pasien tidak perlu lagi diberikan tindakan perawatan yang maksimal tetapi didampingi oleh keluarga dan didoakan. Berikut pernyataan partisipan, yaitu:

“...kalo pasiennya misalnya sudah tidak ada status kemajuan, bisa didampingi dengan keluarga, iya didoakan..."

“...penuhin kebutuhannya, kalau misalnya pasiennya masih sadar ya kita, bantu tanyain untuk BAB, BAK makanya kalau nggak bias ya kita suapin, ya pokoknya kebutuhannya dailnya kita ini sih, kita penuhin..."

“...saat e mulai pasien, kita menilai saat kita masuk, apakah pasien dia perlu perawatan paliatif apa tidak..."

“...nafas - nafas aja nggak bisa, masih perlu dibantu, tensi aja itu dibantu...”

"perawatan paliatif bukannya itu secara keseluruhan, semua, itu mencakup memberikan obat, e kita semualah itu..."

“...saat memberikan obat dan semua, ya karena kita pasti akan ada bersama pasien terus selama jam kerja kita ya..."

“...walaupun dia terminal ya tetap memberikan e perawatan terapi sampai titik penghabisan, pendekatan dengan keluarga untuk mempersiapkan mental mereka untuk menghadapi kematian..."

“...hmp sebenarnya saat pasien masuk intensive kita udah ketahuan oh ini pasiennya apa..."

“...tinggalkan nomor yang bisa dihubungi, nomor telepon keluarga yang bisa dihubungi kalau misalnya terjadi sesuatu sama pasien..."

“...kemudian hadirkan pemuka agama..." 
“...saat kasih obat, saat panggil keluarga untuk memberitahu kondisi pasien, disaat memang pasien butuh untuk mendapatkan perawatan..."

Data berikutnya yang didapat adalah, proses adaptasi yang dialami oleh Key Informant. Dimana beberapa tahun bekerja pada lingkungan yang sama Key Informant merasa senang, lebih bisa dan terbiasa melakukan perawatan pada pasien dibandingkan pada awal mereka melakukan perawatan pada pasien terminal.

Dimana pada pengalama pertama perawat pemula, mengalami rasa takut dalam memberikan perawatan tetapi perawat dapat menyesuaiakan diri dengan lingkungan kerja yang baru.

Menurut Roy, manusia sebagai Sistem Adaptive (dapat menyesuaikan diri). Biasanya ketika mengalami stress atau kelemahan/kekurangan mekanisme coping, biasanya manusia akan berusaha untuk menanggulanginya melalui cara dari pengalaman mereka.

Menurut Supriyadi (2008), pengetahuan juga dapat diartikan sebagai sekumpulan informasi yang dipahami, yang diperoleh dari proses belajar selama hidup dan dapat dipergunakan sewaktu-waktu sebagai alat penyesuaian diri baik terhadap diri sendiri maupun lingkungan.

Pengetahuan seseorang juga diperoleh dari pengalaman hidupnya. Pengalaman membuat seseorang lebih matang dalam mengambil keputusan untuk memecahkan masalah atau mengatasi stres.

Hal ini didukung oleh penelitian Danang (2010) yang menyimpulkan bahwa: Semakin lama bekerja semakin sedikit stres dibanding dengan pengalaman pertama dalam bekerja.

Dari hasil wawancara didapati tiga dari partisipan mengungkapkan setelah beberapa tahun bekerja mereka dapat menyesuaikan diri sehingga lebih terbiasa menghadapi situasi dalam tempat kerja, dan satu partisipan lain mengungkapkan takutnya berangsurangsur hilang dan semua partisipan mengungkapkan merasa lebih senang dalam merawat pasien. Berikut pernyataan

partisipan, yaitu:

“...lama - kelamaan ya takutnya berangsur - angsur jadi nggak takut sih, jadi sudah terbiasa..."

“...senang - senang aja sih selama ini..."

“...pertama baru masuk di ICU, kan harus penyesuaian, butuh penyesuaian yang banyak..."

“...kalo selanjut - selanjutnya mungkin udah lebih terbiasa ya, kita udah tau cara e maksudnya e gimana kita bisa menghadapi e pasien, merasa lebih terbiasa..."

“...merasa senang - senang...”

“...udah lebih terbiasa aja ya sama situasinya..."

“...pergumulan menghadapi mereka karena mereka panik, trus keputusannya labil, tapi sampai sejauh ini sih nggak ya senang - senang aja $\operatorname{sih} \ldots$...

\section{Hambatan Dalam Proses Perawatan}


Tema ketiga yang muncul adalah berdasarkan pengalaman hambatan yang sering dialami selama proses

Kode
Kategori

Tabel 4 Tema ke-3 perawatan, dapat terlihat pada tabel berikut:

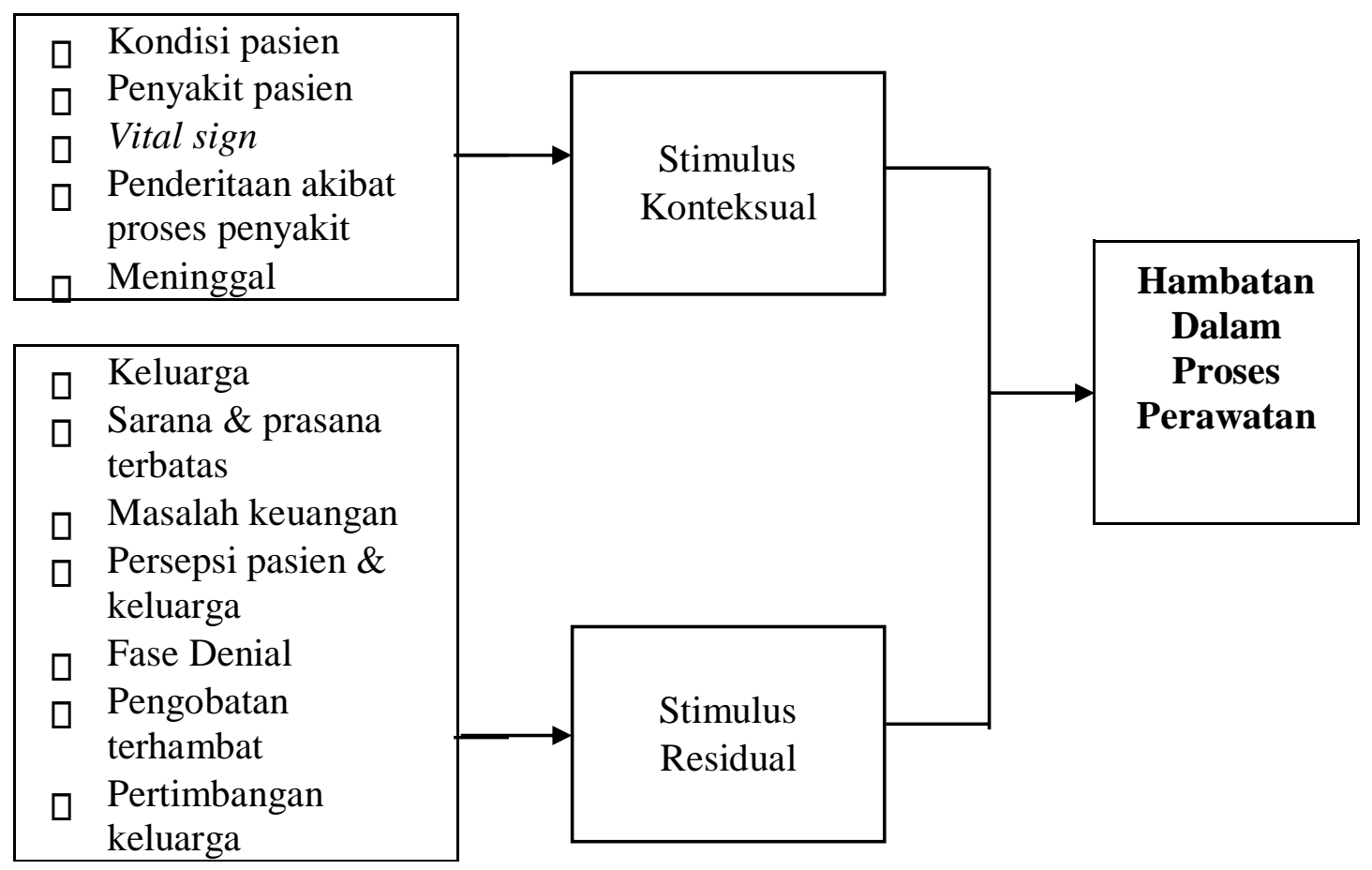

Data yang diperoleh pada saat wawancara adalah hambatan yang dirasakan oleh Key Informant pada pengalaman dalam memberikan asuhan keperawatan paliatif pada pasien terminal. Kondisi yang dialami pasien akibat dari proses penyakit, Vital sign yang sering mengalami perubahan yang signifikan, pasien sering menderita kesakitan akibat proses penyakit dan bahkan sampai meninggal dunia.

Roy mengemukakan bahwa stimulus yang dapat menghambat di kelompokkan menjadi tiga jenis stimulus, antara lain: stimulus fokal, stimulus kontekstual, dan stimulus residual. Key Informant mengalami adanya hambatan dalam proses perawatan yaitu kondisi pasien dari proses penyakit. Sesuai dengan teori Roy hambatan ini kategorikan sebagai stimulus kontekstual.

Stimulus kontekstual yaitu semua stimulus lain baik internal maupun eksternal yang mempengaruhi situasi dan dapat diobservasi, diukur dan secara subyektif dilaporkan. Rangsangan ini muncul secara bersamaan dimana dapat menimbulkan respon negatif pada stimulus fokal.

Sumber stressor yang menjadi hambatan bisa berasal dari orang yang terkena stresor itu sendiri (internal sources) atau dari luar (extemal sources) yang bisa ada pada keluarga 
dan lingkungan baik lingkungan kerja maupun lingkungan sekeliling kita. (Barbara, 2008).

Dari hasil wawancara didapati empat dari partisipan mengungkapkan kondisi pasien dalam proses penyakit menjadi faktor yang menghambat. Berikut pernyataan partisipan, yaitu:

“...kadang - kadang kondisi pasien tersebut ya, kondisi pasien ya udah selesai, sering gitu..."

“...jadi terhambat ya dari pasienya juga, kondisinya..."

“...yang menhambat mungkin dalam kondisi pasien, misalnya tiba - tiba pasien itu e vital signnya e kondisinya menurun..."

“...pernah dulu dirawat di ICU dia meninggal, ya kita merasa itulah yang terbaik buat dia, nggak memperpanjang penderitaanya..."

Data berikut yang diperoleh adalah pengaruh eksternal dalam hal ini stimulus residul. Menurut Roy, stimulus residual yaitu sikap, keyakinan dan pemahaman individu yang dapat mempengaruhi terjadinya keadaan tidak sehat, atau disebut juga dengan Faktor Predisposisi, dimana pengaruh eksternal dapat juga menyebabkan terjadinya kondisi Fokal.

Dalam pengalaman perawat, ditemukan bahwa pada awalnya keluarga dan pasien mengalami fase denial dimana mereka tidak menerima dan menolak proses penyakit, faktor lain yang mendukung stimulus residual adalah masalah keuangan keluarga, persepsi pasien dan keluarga tentang penyakit yang dialami, pertimbangan dan keputusan yang dilakkukan keluarga, dan pengobatan yang terhambat

Pada pengalaman perawat keluarga sering kali mengambil keputusan bersama untuk menghentikan proses perawatan ataupun memilih untuk menghentikan penderitaan pasien dari proses penyakit. Tetapi keputusan yang diambil keluarga, terkadang dilakukan saat mereka sedang dalam kondisi yang tidak stabil sehingga keputusan yang diambil sering berubah - ubah. Hal ini tentu menjadi hambatan dalam proses perawatan.

Karena keluarga adalah orang terdekat pasien yang mempunyai peran yang sangat besar dalam memilih ataupun menentukan dan memberikan

keputusan selama proses perawatan saat pasien dalam keadaan yang kritis. Faktor financial problem keluarga serta sarana dan prasana yang disediakan oleh Rumah Sakit, sering kali juga menjadi faktor eksternal yang dapat mengahambat dalam proses perawatan.

Sumber stressor yang menjadi hambatan bisa berasal dari orang yang terkena stresor itu sendiri (internal sources) atau dari luar (extemal sources) yang bisa ada pada keluarga dan lingkungan baik lingkungan kerja maupun lingkungan sekeliling kita. (Barbara, 2008).

Dari hasil wawancara didapati tiga dari partisipan mengungkapkan keluarga menjadi faktor yang menghambat dalam proses perawatan. Satu partisipan lain mengungkapkan keterbatasan sarana dan prasarana serta 
kondisi financial dari keluarga. Berikut pernyataan partisipan, yaitu:

"...kadang keluarga sih yang menghambat misalnya kita kadang mau memberikan apa keluarga ada disitu jadi kan jadi menghambat..."

“...kadang eh prasarana juga kan suka terbatas kaya misalnya alkes atau apa, kalau misalnya dia pasien umum kalau kita mau apa - apa kan harus, kalau misalnya udah over balance kan harus keluarga suruh ke PBO atau apa gitu..."

“...kadang - kadang dari penerimaan pasien itu sendiri terhadap penyakit dia..."

“...pertamanya kan ada yang dia denial dulu..."

“...keluarga yang memang betul - betul ini kan, yang maksudnya udah stres duluan..."

“...pengobatan itu juga agak terhambat..." “...yang menghambat jika keluarga

tidak siap..."

"...kadang ada yang sudah terminal gitu, sudah tidak mau diapa - apain..."

“...keputusan keluarga nggak mau dilakukan apa - apa ya, kita jadi nggak mau lakuin ya...'

“...kalau keluarga memutuskan untuk jangan kasih ini lagi, sudah cukup begini tapi pengen dirawat disini, itu kan jadi salah satu pertimbangan untuk kita memberikan perawatan..."

\section{Perilaku Caring Perawat}

Tema keempat yang muncul adalah menggambarkan perilaku caring yang diterapkan perawat pada pengalaman merawat pasien terminal, dapat terlihat pada tabel berikut:

Tabel 5 Tema ke-4

\begin{abstract}
Kode
Sukacita, Iklas, Melayani Menganggap pasien sebagai saudara, Rasa kemanusiaan, Memberi Motivasi, Emossional Support, memberi dukungan spiritual

Hasil wawancara yang dilakukan kepada perawat didapati bahwa, dalam memberikan asuhan perawatan paliatif pada pasien perawat juga memberikan caring, sesuai dengan teori yang dikemukakan oleh Watson, tentang perilaku Caring pada seorang perawat.
\end{abstract}

Kategori Tema

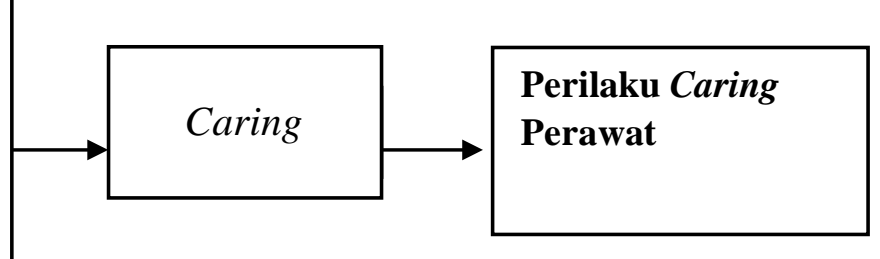

Sesuai dengan hasil wawancara bahwa perawat berkomunikasi dengan pasien dan keluarga, menempatkan pasien sebagai keluarga sendiri yang sedang dirawat, memenuhi kebutuhan spiritual pasien, melayani dengan sepenuh hati, iklas, memberikan dukungan emossional support, motivasi, dan 
semangat kepada pasien dan juga keluarga.

Kepmenkes (2013), perawatan paliatif lebih berfokus pada dukungan dan motivasi ke penderita. Kemudian setiap keluhan yang timbul dari pasien ditangani dengan pemberian obat untuk mengurangi rasa sakit. Perawatan paliatif ini bisa mengeksplorasi individu penderita dan juga keluarganya bagaimana perawat dapat memberikan perhatian khusus terhadap penderitaan, dan penanggulangannya serta kesiapan pasien dan keluarga dalam menghadapi kematian.

Hasil penelitian dari Ardianas, dkk (2010) ditemukan bahwa klien mengharapkan perilaku caring yang holistik sehingga klien puas dengan pelayanan keperawatan. Dengan kemampuan perawat memahami dan mendukung emosi orang lain (dalam hal ini pasien) maka dapat mendorong perawat untuk menerima perasaan klien baik positif maupun negatif sehingga akan tercipta hubungan saling percaya yang merupakan salah satu wujud perilaku caring perawat.

Dari hasil wawancara didapati lima dari partisipan menunjukkan perilkau caring yang baik kepada pasien dan keluarga selama proses perawatan dimana perawat menempatkan pasien sebagai keluarga mereka sendiri, melayani dengan suka hati, iklas, serta senantiasa memberikan motivasi, emossional suport dan memberi dukungan spiritual kepada pasien dan juga keluarga. Berikut pernyataan partisipan, yaitu: “...kalo itu mah dengan e maksudnya dengan suka hati ya, bekerja dengan iklas kan, karena kita melayani berdasarkan Tuhan..."

“...menganggap pasien itu sebagai saudara kita..."

“...perlu ditingkatkan ya mungkin kehadiran pemuka agama..."

“...e sebenarnya dari hati nurani...”

“...coba tempatkan diri kita kalau nggak keluarga kita, orang tua kita diposisi seperti itu, harusnya kita lebih perhatian ha a lebih care..."

“...kemanusiaan aja, rasa kemanusiaan yang mendorong memberikan perawatan..."

“...ya kita dukung kita kasih motivasi, pasien semangat, kasih emosional support, anjurkan banyak berdoa biar lebih iklas..." K6

\section{Development of self efficacy}

Tema kelima yang muncul ini dapat terlihat pada tabel berikut: 
Tabel 6 Tema ke-5

Kode

Kategori

Tema

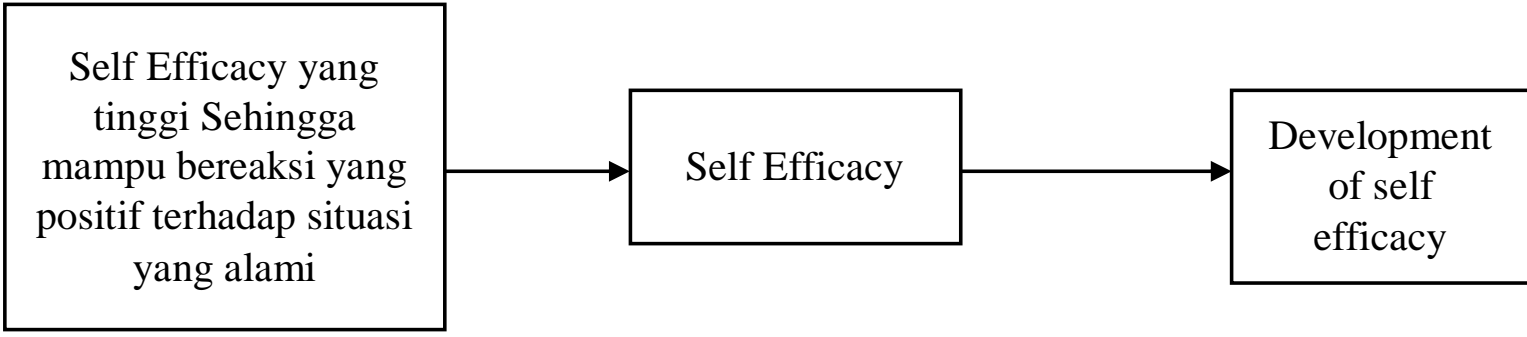

Dari hasil wawancara didapatkan bahwa seluruh Key Informant mempunyai effikasi diri yang tinggi sehingga mampu untuk bereaksi yang positif tehadap situasi yang dialami selama proses perawatan.

Menurut Octary (2008), seorang perawat yang memiliki keyakinan yang tinggi bahwa ia mampu melaksanakan tugas dengan baik, akan memiliki kepercayaan diri yang tinggi pula dalam melaksanakan pekerjaannya sehingga ketika menghadapi situasi kurang kondusif. Perawat dapat mampu menanggulangi situasi tersebut secara efektif tanpa terlihat ragu-ragu dan cemas.

Self efficacy yang tinggi membantu individu untuk menyelesaikan tugas dan mengurangi beban kerja secara psikologis maupun fisik. Rutinitas pekerjaan yang memiliki tingkat kesulitan yang tinggi dan jam kerja yang cukup panjang, seorang perawat yang memiliki self efficacy tinggi tidak akan mudah mengalami stres dalam pekerjaanya.

Perawat yang merasa tidak yakin dengan kemampuannya cenderung mudah merasa cemas dan mudah menyerah dalam menghadapi hambatan. Mereka tidak akan melakukan upaya apapun untuk mengatasi hambatan yang ada, karena percaya bahwa tindakan yang mereka lakukan tidak akan membawa pengaruh apapun.

Rachmawati (Khotimah, 2010), menyebutkan hasil survei yang dilakukan Persatuan Perawat Nasional Indonesia (PPNI) tahun 2006, menunjukkan sekitar $50,9 \%$ perawat yang bekerja di empat profinsi di Indonesia mengalami stres kerja. Perawat sering mengalami pusing, lelah, tidak bisa istirahat karena beban kerja yang tinggi dan menyita waktu. Tidak berbeda jauh, hasil data yang dihimpun PPNI pada Mei 2009 di Makassar juga menunjukkan 51\% perawat mengalami stres kerja, pusing, lelah, kurang istirahat karena beban kerja yang terlalu tinggi.

Angka ini hanya menunjukkan sebagian kecil dari keseluruhan jumlah perawat yang mangalami stres kerja di beberapa wilayah di Indonesia. Apabila survei tersebut dilakukan di seluruh wilayah Indonesia maka jumlahnya 
tentu sangat besar. Hal ini tentu saja akan mengganggu kualitas pelayanan yang diberikan oleh rumah sakit, khususnya oleh perawat itu sendiri.

Apabila perawat terus menerus mengalami kecemasan karena merasa tidak mampu dalam menjalankan tugasnya dengan baik maka ia rentan mengalami stres kerja. Hal ini sesuai dengan pendapat dari Bliese, dkk (dalam Mariza, 2011), yang menyatakan bahwa pekerjaan pun dapat benar-benar menjadi ancaman dan sumber stres bagi individu yang tidak memiliki keyakinan dan self efficacy tinggi.

Teori Self Efficacy pertama kali dikembangkan oleh Bandura (dalam Ghufron, 2010). Ia menyatakan bahwa self efficacy adalah keyakinan individu mengenai kemampuan dirinya dalam melakukan tugas atau tindakan yang diperlukan untuk mencapai hasil tertentu.

Dari hasil wawancara didapati lima dari partisipan menunjukkan hasil yang positif. Dimana partisipan memiliki Self Efficacy yang tinggi, dan mampu memberikan respon yang baik dalam memberikan perawatan serta memiliki managament stress yang baik dalam pekerjaan. Berikut pernyataan partisipan,

yaitu:

“...lama kelamaan ya takutnya berangsur - angsur jadi nggak takut sih jadi sudah terbiasa..."

“...merasa senang - senang saja sih selama ini..." “...jadi keluarga juga terharu sih, e benar - benar mengucapkan terimakasih ke kita, karena sudah $e$ mambantu dan merawat itu dengan baik dan menjaga..."

“...perasaannya mah biasa aja nggak ada perasaan takut..."

“...merasa lebih terbiasa dan juga setidaknya pelayanan yang kita berikan juga itu, jadi lebih berkualitas gitu..."

"...kalau saya tidak merasa ada pengalaman yang tidak menyenangkan ya, merasa senang - senang saja selama ini..."

“.... sebagai pegawai dan perawat pasti memberikan sesuai dengan profesi kita dan tanggung jawab kita dalam pekerjaan dan pelayanan kita, tetap harus diberikan sesuai dengan prosedur yang sudah ada..."

“...tentunya mereka bisa terima kita lah ya karena kita ada disampingnya..."

“...perasaanya sama seperti merawat pasien yang lain, nggak ada rasa takut sih, biasa aja..."

“...ya tetap kita harus melakukan kewajiban kita, tetap harus kita kasih perawatan..."

“...melihat penderitaan ya gitu kitapun ikut merasaitu yang terbaik untuk dia iya kan nggak memperpanjang penderitaanya..."

“...sampai sejauh ini nggak ada pengalaman yang tidak 
menyenangkanya, senang - senang aja sih..."

\section{KESIMPULAN DAN SARAN}

Kesimpulan yang diperoleh dari penelitian yang telah dilakukan pada keenam Key Informant, dengan judul "Studi Fenomenologi Pengalaman Perawat Dalam Memberikan Asuhan Keperawatan Palaitif Pada Pasien Dengan Penyakit Terminal Diruang ICU Rumah Sakit Advent Bandung, didapatkan 5 tema antara lain :

1. Koping perawat pada pengalaman perawat dalam memberikan asuhan perawatan paliatif ditemukan hasil bahwa perawat memiliki mekanisme koping yang baik dalam pengaturan stres selama melakukan proses perawatan dan dalam menghadapi keluarga.

2. Adaptasi perawat pada pengalaman perawat dalam memberikan asuhan perawatan paliatif ditemukan hasil bahwa perawat mengalami proses adaptasi yang baik. Perawat mengalami peningkatan yang progresif. Dari novice atau perawat pemula menjadi perawat proficient atau perawat yang cakap dalam pekerjaannya yang dapat memberi pelayanan perawatan secara menyeluruh atau holistik serta mampu melibatkan keluarga dalam perawatan.

3. Hambatan dalam proses perawatan pada pengalaman perawat dalam memberikan asuhan perawatan paliatif ditemukan hasil bahwa terdapat dua stimulus yang menjadi hambatan dalam memberikan perawatan, yaitu stimulus kontekstual, stimulus ini berasal dari kondisi pasien akibat proses penyakit. Kedua adalah stimulus residual, stimulus eksternal dalam hal ini keluarga, masalah keuangan, juga sarana dan prasana yang terbatas, tetapi keluarga memiliki pengaruh yang besar dalam pengambilan keputusan.

4. Perilaku caring perawat pada pengalaman perawat dalam memberikan asuhan perawatan paliatif ditemukan hasil bahwa walaupun tidak memahami secara utuh perawatan paliatif tetapi perawat mampu menerapkan perilaku caring yang baik selama melakukan proses perawatan.

5. Development of self-efficacy pada pengalaman perawat dalam memberikan asuhan perawatan paliatif ditemukan hasil bahwa perawat memiliki effikasi diri yang tinggi sehingga mampu bereaksi yang positif selama melakukan proses perawatan.

\section{Saran}

Peneliti memberikan saran dari hasil penelitian yang dapat berguna bagi perawat, rumah sakit, dan bagi bidang penelitian.

\section{Perawat}

Hasil penelitian ini dapat menjadi masukan bagi perawat dalam memberikan asuhan keperawatan pada pasien terminal sesuai dengan kode etik perawat dan panduan perawatan paliatif.

Serta perawat dapat memperlengkapi diri dengan mengikuti seminar seminar, workshop ataupun pelatihan paliatif guna meningkatkan pengetahuan dan ketrampilan dalam perawatan palaitif

\section{Rumah Sakit}

Hasil penelitian ini dapat menjadi masukan dan pertimbangan bagi Rumah Sakit khususnya untuk memenuhi dan meningkatkan proses 
perawatan paliatif pada pasien terminal yang secara menyeruluh.

Berdasarkan hasil penelitian didapati bahwa untuk meningkatkan proses perawatan paliatif Rumah Sakit perlu memberikan seminar - seminar tentang perawatan paliatif, serta membuka pelatihan paliatif yang dapat diikuti oleh setiap tim kesehatan khususnya mereka yang bekerja pada Ruang Perawatan Kritis sehingga dapat memberikan pengetahuan dan ketrampilan yang sesuai dengan kebutuhan pada perawatan paliatif.

Serta menghadirkan pemuka agama diluar agama advent untuk memenuhi kebutuhan spiritual dan agama pasien yang sedang dirawat maupun juga keluarga pasien. Membuat ruangan khusus untuk perawatan paliatif dan menempatkan perawat serta tim kesehatan lainnya yang secara khusus untuk perawatan paliatif apabila terjadi peningkatan kebutuhan pasien akan perawatan paliatif di Rumah Sakit Advent.

\section{Bidang Penelitian}

Penelitian ini diharapkan dapat menjadi data dasar tentang perawatan paliatif serta dapat juga dikembangkan dalam penelitian lain, seperti: pengalaman keluarga merawat pasien paliatif, atau tingkat pengetahuan perawat dalam menerapkan perawatan paliatif.

\section{DAFTAR PUSTAKA}

Asmadi. (2008). Konsep Dasar Keperawatan. Jakarta: EGC

Adhisty, Effendy, Setiyarini. (2016). Pelayanan Paliatif pada Pasien Kanker di RSUP

Dr.
Sadjito Yogyakarta.

Tesis.etd.repository.ugm.ac.id/... /95916/.../S2-2016-352965abstract.pdf

Ari, M., \& Insook, K. (2013). Relationship of perception of clinical ladder system with professional self concept and empowerment based of nurses' clinical career stage. Journal of Korea Academy of Nursing Administration, 19 (3), 254-264.

Bandura, A. (1997). Self Efficacy: The Exercise of Control. USA: W.H. Freemen dan Company

Barbara, JS, (2008) . Adaplation and Growth Growth Psyhiatric Mental Health Nursing,Fourth edition, Lippincott.

Campbell, M. L. (2013). Nurse to nurse: perawatan paliatif. Diterjemahkan oleh Daniaty, D. Jakarta: Salemba Medika

Danang,P.(2009). Hubungan Stres Kerja Dengan Adaptasi Pada Perawat DiInstalasi Gawat Darurat Rsud Pandan Arang. Diakses pada tangga 25 April 2018 darihttp://etd.eprints.ums.ac.id

Effendi, F \& Makhfudli. (2009). Keperawatan Kesehatan Komunitas: Teori dan Praktek Dalam Keperawatan. Jakarta: Salemba medika

Ferrell, B., Virani, R., Paice, J. A., Coyle, N., \& Coyne, P. (2009). Evaluation of palliative care 
nursing education seminars. European Journal of Oncology Nursing, 14, 74-79

Ferrell, B.R., Virani R., Paice, J.A., Malloy, P., \& Dahlin, C. (2010). Statewide efforts to improve palliative care. Critical Care Nurse. Diakses dari http://www.ccnonline.org.

Foster, George M. \& Anderson, Barbara Gallatin. (2008). Medical Antropology. New York: John Wiley \& Sons, Inc.

Ghufron, M. Nur \& Rini Risnawita .S. (2010). Teori-teori Psikologi.Jogyakarta: Ar-ruzz Media.

Herdiansyah, H. (2010). Metodologi Penelitian Kuantitatif. Jakarta: Salemba.

Kemekes RI. (2007) Keputusan Menteri Kesehatan Republik Indonesia Nomor:

812 /Menkes/SK/VII/ 2007 Tentang

Kebijakan

PerawatanPaliatif.Jakarta

Kemenkes RI. (2013). Pedoman Teknis Pelayanan Paliatif Kanker. Jakarta.

Kemenkes RI . (2016). Panduan Asuhan Keperawatan Paliatif di Rumah. Jakarta

Khotimah, Kusnul. 2010. Hubungan antara Persepsi terhadap Lingkungan Kerja
Psikologis dengan burn out pada Perawat RSU Budi Rahayu Pekalongan. Semarang: FPUNDIP. Latour J. M., Fulbrook, P., \& Albarran, J. W.(2009). EfCCNa survey: European intensive care nurses' attitudes and beliefs towards endof-life care. Nursing in Critical Care, 14 (3), 110-121.

McIlfatrick, S., Mawhinney, A., \& Gilmour, F. (2010). Assessing the educational needs of palliative care link nurses. International Journal of Palliative Nursing, $16(11)$.

Moleong, L. J. (2016) Metodologi Penelitian Kualitatif, Penerbit PT Remaja Rosdakarya Offset, Bandung.

National Consensus Project for Quality Palliative Care. (2010). Clinical Practice Guidelines Domain

Notoatmodjo, S. (2010) Metodologi Penelitian Kesehatan. Cetakan 3. Jakarta: Asdi Mahastya

Oktary, M. Anton. (2008). Hubungan antara Self Efficacy dengan Kecemasan pada Mahasiswa yang sedang Mengerjakan Skripsi. Depok: FPUI.

Potter \& Perry. (2010). Fundamental Of Nursing: Consep, Proses and Practice. Edisi 7. Vol. 3. Jakarta: EGC

Semiawan, R.(2010). Metode Penelitian Kualitatif. Jakarta: Grasindo. 
Sitinjak, L. (2008). Pengaruh penerapan sistem jenjang karir terhadap kepuasan perawat di RS PGI "Cikini" Jakarta. Tesis tidak dipublikasikan. Depok: FIK UI

Streubert, H, \& Carpenter, D. (1999). Qualitative Research in Nursing: Advancing the Humanistic Perspective (2nd ed.). Philadelphia.

Sugiyono (2011) . Metode penelitian kuntitatif kualitatif dan R\&D. Alfabeta

Sujarweni,W. (2014).

MetodePenelitian.Yogyakarta: Pustaka Baru Press

Thomas, Linda, Finch, Schoenhofer, dan Green (2009) J.D, Finch.L.P., Schoenhofer. S.O. (2005). The caring relationship created by nurse practitioners and the ones nursed: Implication for practice. http://www.medscape.com diperoleh 25 April 2018.

Wahyuni, R. (2014). Hubungan Kesiapan Orang Tua Dengan Kualitas Hidup Anak Yang Menderita Penyakit Terminal Dalam Perawatan Paliatif Di Yayasan Rumah Rachel. Jakarta: Universitas Esa Unggul Jakarta.

Diakses pada 10

Desember 2017, dari

https://www.scribd.com/docume

$\mathrm{nt} / 362182070 / \mathrm{UEU}$ -

Undergraduate-3425-BABI
Wasis, (2006). Pedoman Riset Praktis Untuk Profesi Keperawatan. Jakarta: EGC

Watson, J. (2008). Original center for human caring. http://www2.uchsc.edu Diakses 25 April 2018.

Wills, Evelyn. (2011) . Theoretical Basis for Nursing.

World Health Organization (2011), Palliative Care For Older People: Better Practices.Europe

World Health Organization. (2014). Global Atlas of Palliative Care at the End of Life. Europe 